\title{
めっきおよび空気抜き円形孔に生じる溶融亜鉛めっき割れに関する基礎的研究 FUNDAMENTAL STUDY ON LIQUID METAL ASSISTED CRACKING
OCCURRED AT VENT AND DRAIN HOLES DURING HOT-DIP GALVANIZING
}

\author{
浅田勇人 ${ }^{* 1}$, 田中 剛*2, 山下達雄 ${ }^{* 3}$, 藤原有希*4 \\ Hayato ASADA, Tsuyoshi TANAKA, Tatsuo YAMASHITA \\ and Yuki FUJIWARA
}

\begin{abstract}
This paper focuses on the effect of geometrical parameters on the occurrence of liquid metal assisted cracking (LMAC) initiated from the edge of vent and drain holes. The immersion tests and corresponding FEA were performed with the scaled specimens to investigate the temperature and strain histories during hot-dip galvanizing. From the investigation, the tensile strain increased as flange-to-web thickness ratio increased, and as the web thickness decreased, expanding the diameter of drain hole somehow reduced strain concentration. Overall, the increase in tensile strain results in significant increase in LMAC, regardless of geometrical configuration.
\end{abstract}

Keywords: Hot-dip galvalizing, Lquid Metal assisted cracking , Drain hole, Immersion tests, Heat transfer analysis, Thermal stress analysis 溶融亜鉛めっき工法，溶融亜鉛めっき割れ，めっき抜き孔，浸漬実験，熱伝導解析，熱応力解析

\section{1. はじめに}

鋼部材の溶融亜鉛めっき施工では，鋼部材の隅角部におけるめっ き溜まりや，空気溜まりによる不めっきを避けるために，空気・めっ き抜き孔 ( 以下，めっき抜き孔) を設ける必要がある。柱梁接合部に おいて, Fig. 1 (a) に示すスカラップをめっき抜き孔とする場合，ス カラップおよび溶接止端の形状に伴う歪集中や, 溶接に伴う残留応 力の影響が大きくなるため, 溶融亜鉛めっき脆化割れ ( 以下，めっき

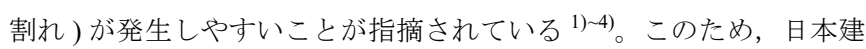
築学会・鉄骨工事標準仕様書 (JASS6) ${ }^{5), 6)}$ では, Fig. 1 (b) に示すとお り梁端接合部をノンスカラップ形式とし，めっき抜き孔として梁ウェ ブに円形孔を別途設けることが推奨されている。しかしながら，Fig. 1(b) のディテールを用いることで，めっき割れの発生頻度は低減で きるものの, めっき割れの発生は依然認められている。

これまでに建築鉄骨のめっき割れに関する研究としては，590N/ $\mathrm{mm}^{2}$ 級高張力綱を用いた送電鉄塔用部材の溶接熱影響部に生じる めっき割れを対象として精力的に研究が行われてきた。これらの研 究から, めっき割れが旧オーステナイト粒界にめっきが侵入するこ とによる粒界強度の低下によってもたらされ，この現象が鋼材の化 学成分, 特に, 微小ボロンと強い相関があることが報告されている例 えば 7) 10)。また，これらの検討を基に，鉄塔用高張力鋼鋼材の JIS 規

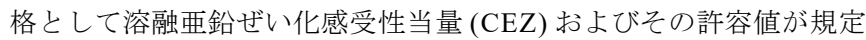
されている。

また，我が国では，柱に冷間成形角形鋼管を用いることが多いが，

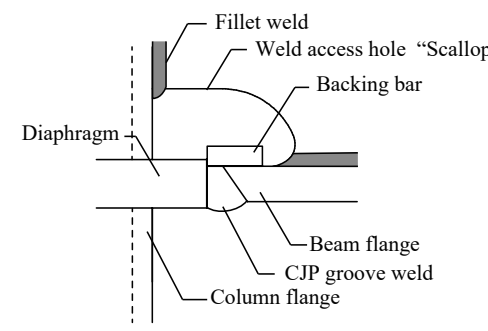

(a) Single-sided CJP weld with weld access hole

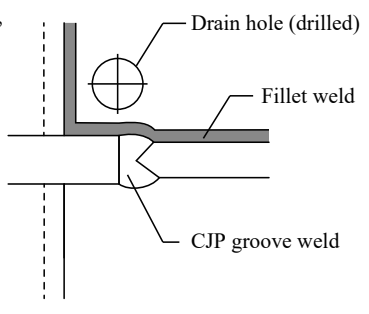

(b) Back-gouged double-sided CJP weld without weld access hole (recommended details in JASS 6 (AIJ))

Fig.1 Details of welded beam-column connections
この冷間成形角形鋼管の角部に生じるめっき割れについては，鋼材 内の初期残留引張応力が大きくなることで, 増大寸ることが示され ており，その対策として，角部の不めっき処理が有効とされている 11)

一方で，本研究が着目する円形孔を起点としためっき割れついて は，溶接熱影響部ではなく，母材原質部に相当する位置で生じる割 れである。また，極端に円形孔を溶接止端に近づけない限りは，溶 接による残留応力の発生も, 冷間加工に伴う残留応力に比べれば小 さいものと考えられる。

以上を踏まえて，本論では，梁端ウェブ近傍に設けられる円形孔 を起点に生じるめっき割れの発生メカニズムおよびその効果的な防 止策を明らかにする端緒として，ウェブとフランジの板厚比，ウェ ブの板厚，円形孔径およびその位置といった幾何学的パラメータに
*1 神戸大学大学院建築学専攻 助教 $\cdot$ 博士 $($ 工学 $)$

*2 神戸大学大学院建築学専攻 教授·博士 (工学)

* 3 角藤 工博

*4 清水建設 (元神戸大学大学院生)
Assist. Prof., Dept of Architecture, Kobe University, DrEng.

Prof., Dept. of Architecture, Kobe University, Dr.Eng.

Kakuto Corporation, Dr.Eng.

Shimizu Corporation, M.Eng. (Former Grad. Student, Kobe University) 
Table 1 Material properties of steel used for web

\begin{tabular}{|c|c|c|c|c|c|c|c|c|c|c|c|c|c|}
\hline \multirow[b]{2}{*}{ Thickness } & \multirow[b]{2}{*}{ Grade } & \multicolumn{3}{|c|}{ Coupon test results } & \multicolumn{9}{|c|}{ Chemical composition wt (\%) } \\
\hline & & $\begin{array}{c}\text { Yield strength } \\
\mathrm{N} / \mathrm{mm}^{2} \\
\end{array}$ & $\begin{array}{c}\text { Tensile strength } \\
\mathrm{N} / \mathrm{mm}^{2} \\
\end{array}$ & $\begin{array}{c}\text { Elongation } \\
\% \\
\end{array}$ & $\mathrm{C}$ & $\mathrm{Si}$ & $\mathrm{Mn}$ & $\mathrm{Ni}$ & $\mathrm{Cr}$ & Mo & $\mathrm{V}$ & B & $\begin{array}{c}\text { CEZ } \\
\% \\
\end{array}$ \\
\hline PL-9 & \multirow{3}{*}{ SN490B } & \begin{tabular}{|l|}
375 \\
\end{tabular} & 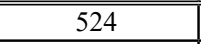 & 29 & 0.17 & 0.34 & 1.39 & 0.01 & 0.00 & 0.01 & 0.005 & 0.00048 & 0.58 \\
\hline PL-12 & & 372 & 533 & 26 & 0.17 & 0.37 & 1.41 & 0.01 & 0.02 & 0.01 & 0.002 & 0.00010 & 0.43 \\
\hline PL-14 & & 402 & 549 & 26 & 0.17 & 0.32 & 1.33 & 0.02 & 0.03 & 0.01 & 0.00 & 0.00010 & 0.42 \\
\hline
\end{tabular}
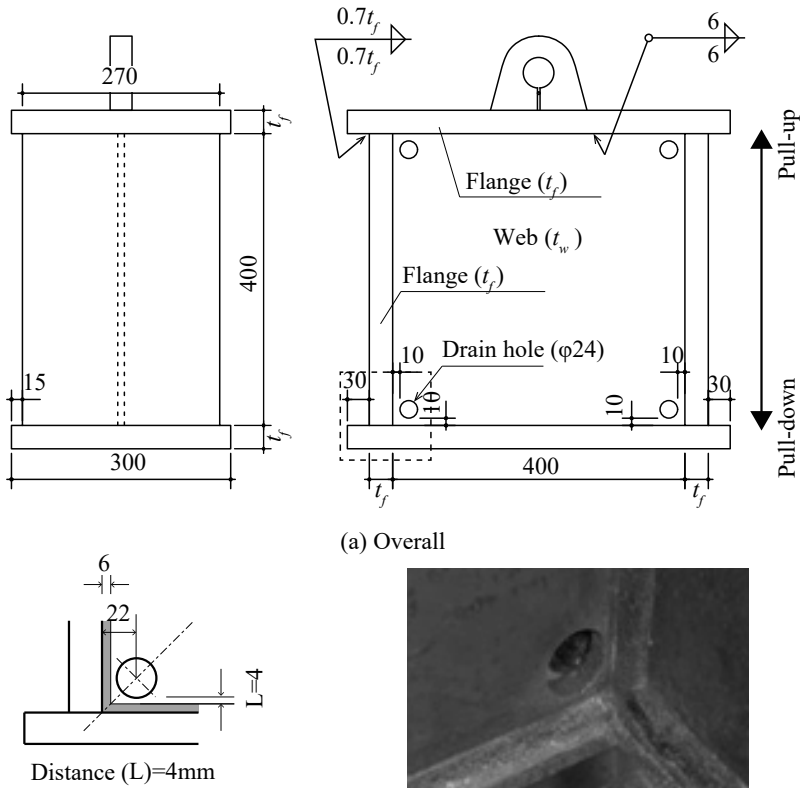

(b) Detail around drain hole (a) Overall

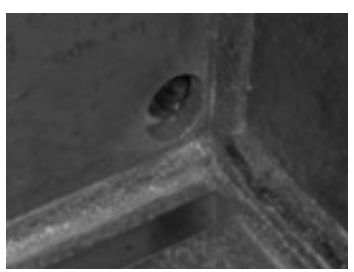

(c) Welding near the hole

Fig. 2 Test specimen

着目し, 各種パラメータが円形孔縁の歪性状に与える影響, さらに はめっき割れとの対応を調べることを目的とした。具体的には，建 築構造物に多用される $490 \mathrm{~N} / \mathrm{mm}^{2}$ 級鋼材 SN490B を用いて単純模型 試験体を製作し, 浸漬測定実験および熱伝導一熱応力解析を行い, 実験による温度・歪性状の把握，解析の再現性の検討，さらには， 割れ発生位置の歪性状に基づく各種幾何学的パラメータの影響分析 を行った。

\section{2. 浸漬測定実験と熱伝導 - 熱応力解析}

\section{1 実験計画}

まず，溶融亜鉛めっき浸漬中の歪および温度履歴性状を調べるた めに，梁端接合部を部分的に再現した単純模型試験体を用いた浸漬 測定実験を行った。単純模型試験体の形状を Fig. 2 に示す。試験体 は Fig. 2(a) に示すとおり，梁ウェブを模した鋼板 (SN490B)の 4 辺を 柱および梁フランジを模した鋼板 (SN490B) によって外周を囲む形状 とした。ウェブ厚 $t_{w}$ はいずれも $9 \mathrm{~mm}$, 柱および梁フランジ厚 $t_{f}$ は 19 および $32 \mathrm{~mm} の 2$ 種類 (それぞれ T19 と T32) とした。梁ウェブの四 隅には，めっき抜き孔として $\phi 24$ のドリル孔を設けた。 $\mathrm{T}$ 継手の隅 肉溶接は, $1.4 \mathrm{~mm} \phi$ フラックス入りワイヤを用い, 炭酸ガスシール ドアーク溶接法で施工した。ウェブとフランジの隅肉溶接は，ウェ ブの板厚にかかわらず, Fig. 2(b) に示すようにサイズを $6 \mathrm{~mm}$ とし, 溶接入熱の目標を $14 \sim 15 \mathrm{~kJ} / \mathrm{cm}$ の範囲に管理して施工した。四隅部 の溶接後外観の例を Fig. 2(c) に示す。ウェブ側の溶接止端と孔縁間 の最短距離の実測值は概称 $3 \sim 5 \mathrm{~mm}$ の範囲となっており設計上の寸

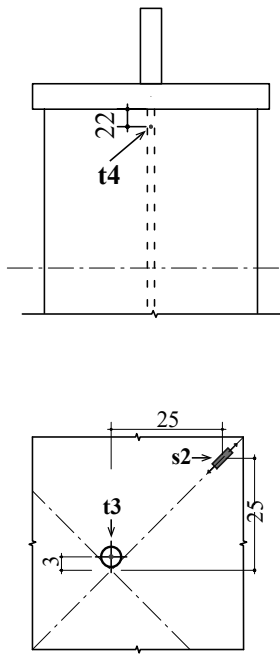

(b) Enlarged view A

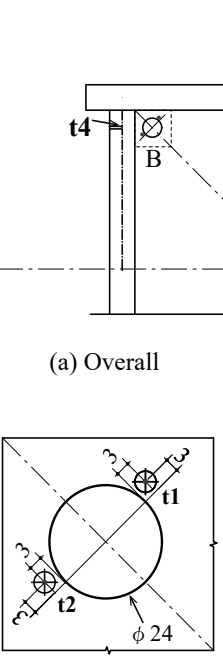

(c) Enlarged view B
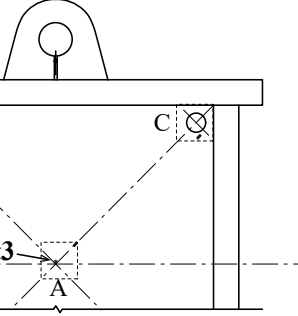

$\mathrm{s} \sim$ : Strain guage $\mathrm{t} \sim$ : Thermo couple

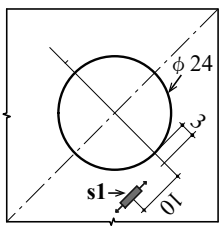

(d) Enlarged view $\mathrm{C}$
Fig. 3 Position of strain gauges and thermocouples

法である $4 \mathrm{~mm}$ とほぼ一致することを確認した。ウェブに使用した鋼 材の引張試験結果および化学成分の分析結果を Table 1 に示す。なお, PL-12 および PL-14 は, 第 3 章の浸漬実験の試験体ウェブに使用した 材料である。化学成分の分析結果に基づき CEZ を算出したところ, PL-9 では，ボロンの含有量が 4.8ppm であり, JIS G3129 に示される 許容值 (CEZ $\leqq 0.44 \%)$ を上回り，PL-12 および PL-14 は，若干下回っ ている。

溶融亜鉛めつき施工条件について述べる。本実験では実施工の範 囲で最も温度勾配が大きくなる条件を設定することを意図し，めつ き浴槽の温度を $445^{\circ} \mathrm{C}$ ( 実測温度 : $446^{\circ} \mathrm{C}$ ) とし, 浸漬・引上げ速度 は施工可能な範囲で最も遅い $0.5 \mathrm{~m} / \mathrm{min}$., 浸漬時間は 8 分とした。試 験体の浸漬・引上げは, 試験体の温度変化に及ぼす要因を減ずるため, Fig. 2 に示寸矢印の方向に試験体を水平に保持して行った。

温度測定および歪測定位置を Fig. 3 に示す。温度測定には $\mathrm{K}$ 型熱 電対を使用した。熱電対はそれぞれ板厚中央位置まで穴を開け，穴 の底部に取り付けた。歪測定には, 高温用溶接型歪ゲージを使用した。 歪ゲージは, めっき抜き孔近傍 $\mathrm{s} 1$ とウェブ中央付近 s2 の計 2 箇所に, 亀裂の進展が予想される方向に対して直交寸る 45 度方向（図の一点 鎖線と平行となる方向）向けて貼付した。

めっき割れの検出は，目視及び磁粉探傷試験を併用して行った。

\section{2 解析計画}

浸漬実験の再現性の検証およびめつき割れ発生位置の詳細挙動を 検討するために，汎用有限要素解析プログラム ABAQUS ver6.11-2 ${ }^{12)}$ を用いた一方向連成熱伝導 - 熱応力解析を行った。

解析モデルをFig. 4 に示す。解析モデルは 3 次元ソリッド要素を 用いて作成し，温度境界条件および形状の対称性を考慮した $1 / 4$ モデ ルとした。熱伝導解析における温度初期条件は，実験条件に合わせ 


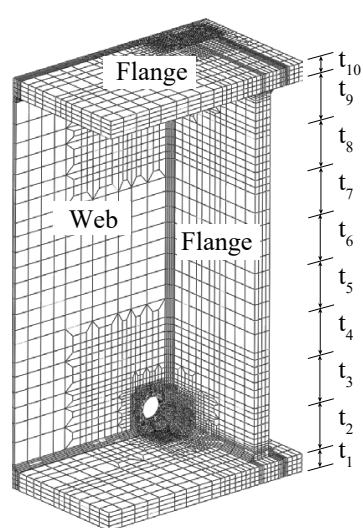

(a) Overall
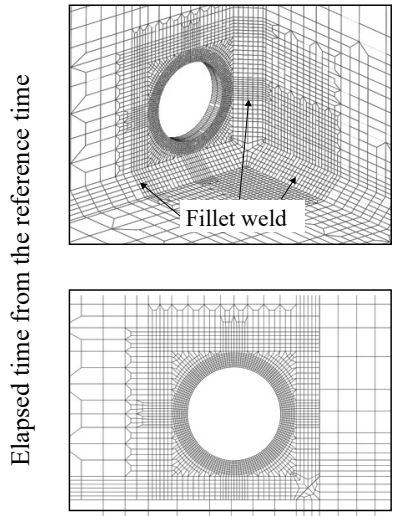

(a) Details around hole

Fig. 4 FE model

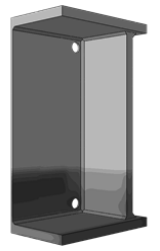

(a) $t_{3} \sec$

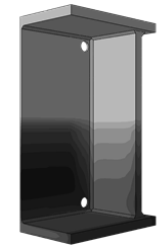

(b) $t_{5} \mathrm{sec}$

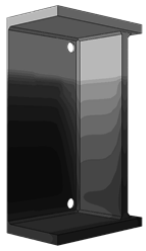

(c) $t_{7} \mathrm{sec}$

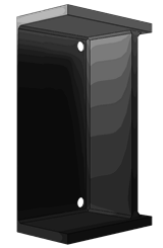

(d) $t_{9} \sec$

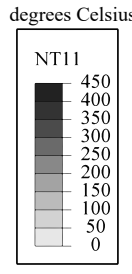

Fig. 5 Reproduction of thermal conditions during hot-dip galvalizing

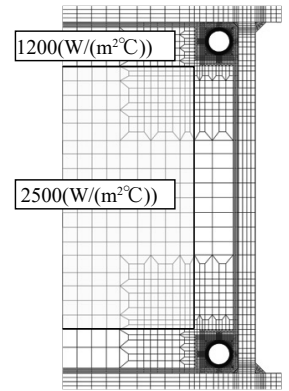

(a) Distribution of heat transfer coefficient

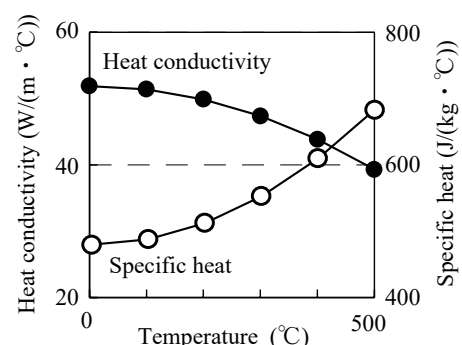

(b) Temperature dependence of heat conductivity and specific heat
Fig. 6 Thermal properties of steel for thermal transfer calculation

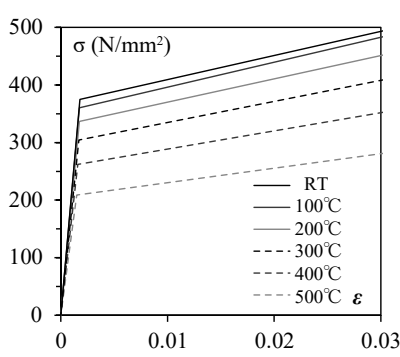

\begin{tabular}{|c|c|c|c|}
\hline $\begin{array}{c}\theta \\
\text { (degrees })\end{array}$ & $\mathrm{E}(\theta) / \mathrm{E}_{0}$ & $\sigma_{\mathrm{y}}(\theta) / \sigma_{\mathrm{y} 0}$ & $\mathrm{C}(\theta) / \mathrm{C}_{0}$ \\
\hline 100 & 0.98 & 0.96 & 1.00 \\
\hline 200 & 0.94 & 0.90 & 0.93 \\
\hline 300 & 0.88 & 0.81 & 0.84 \\
\hline 400 & 0.80 & 0.70 & 0.73 \\
\hline 500 & 0.68 & 0.56 & 0.58 \\
\hline
\end{tabular}

NOTE: $\mathrm{E}_{0}, \sigma{ }_{\mathrm{y} 0} \mathrm{C}_{0}$ are Elastic modulus, yield strength, and strain-hardening coefficient at RT respectively.

Fig. 7 Mechanical properties of steel for thermal stress calculation

て溶融亜鉛温度を $446^{\circ} \mathrm{C}$, 鋼材温度を $40^{\circ} \mathrm{C}$ と設定した。試験体の浸 漬過程における温度分布の一例を Fig. 5 に示す。本解析では, 浸漬速 度の影響を考慮するために, 最初に $T_{1}$ 秒後の浸漬領域, 次に $T_{2}$ 秒後 の浸漬領域というように時間毎に熱境界面を計 10 段階に分けて再定 義した。各部の熱伝達率，比熱および熱伝導率をFig. 6 に示す。亜 鉛と鋼材間の熱伝達率は, Fig. 6(a) に示すようにウェブ中央付近を $2500 \mathrm{~W} /\left(\mathrm{m}^{2} \cdot{ }^{\circ} \mathrm{C}\right)^{13)}$, フランジおよびフランジ近傍のウェブを $1200 \mathrm{~W} /$ $\left(\mathrm{m}^{2} \cdot{ }^{\circ} \mathrm{C}\right)$ と設定した。フランジおよびフランジ近傍のウェブの熱伝
達率は，後述する熱履歴の実験結果と解析結果の整合を図るように 設定したものである。比熱および熱伝導率は, Fig. 6(b) に示すとおり， 鋼構造耐火設計指針 ${ }^{14)}$ に準拠して温度依存性を考慮した。

熱応力解析に用いた鋼材の一方向応力ー歪関係の一例 (ウェブ : $9 \mathrm{~mm})$ を Fig. 7 に示寸。本解析では各等温過程における応力一歪関係 を簡潔なバイリニア型として与えることを意図し，Lie の方法 ${ }^{15)}$ に 従ってモデル化した。線膨張係数およびポアソン比は温度に依らず, それぞれ $1.2 \times 10^{5}\left(1 /{ }^{\circ} \mathrm{C}\right)$ および 0.3 と仮定した。塑性域における構 成方程式は, von Mises の降伏条件, 連合流れ則および線形移動硬化 則に従うものとした。本論で用いた構成則の温度依存性を若干補足 しておく。降伏関数 $F$ は, 各温度 $\theta$ 時の降伏応力 $\sigma_{y}(\theta)$ を用いて, 以 下の通りに表される。

$$
F=\sqrt{\frac{2}{3}(\mathbf{S}-\boldsymbol{\alpha}):(\mathbf{S}-\boldsymbol{\alpha})}-\sigma_{y}(\theta)
$$

ここで， $\mathbf{S}$ および $\boldsymbol{\alpha}$ は，それぞれ偏差応力テンソルおよび背応力 の偏差成分である。

すなわち，本解析では溶融亜鉛めっきに浸漬することによる鋼材 の温度上昇に伴って $\sigma_{y}(\theta)$ は低下寸るので, $F$ によって与えられる降 伏曲面は収縮していくことになる。

降伏曲面の移動を規定する背応力の発展方程式は， $\sigma_{y}(\theta)$ および歪 硬化パラメータ $\mathrm{C}(\theta)$ を用いて, 次式で表される。

$$
d \boldsymbol{\alpha}=\frac{C(\theta) \cdot d \bar{\varepsilon}^{p}}{\sigma_{y}(\theta)}+\frac{d C(\theta)}{C(\theta)} d \theta \cdot \boldsymbol{\alpha}
$$

ここで， $d \bar{\varepsilon}^{p}$ は相当塑性歪速度である。

(2) 式より，本解析の硬化特性は，鋼材の絶対温度 $\theta$ のみに依存す る項を除けば， $d \bar{\varepsilon}^{p}$ の他に温度変化 $d \theta$ に依存することになる。

\section{3. 実験結果および解析結果}

\subsection{1 めっき割れの発生状況}

めっき割れの発生例を Fig. 8 に示す。めっき割れはフランジ厚 $t_{f}$ が $19 \mathrm{~mm}$ である T19 では発生せず， $t_{f}$ が $32 \mathrm{~mm}$ の T32 では上部 2 箇所の 円形孔で生じた。また，T32 の上部 2 箇所のめっき割れは，いずれも 想定通り Fig.8(b) に示すようなウェブの対角線方向に直交するように 進展している。この割れ形態は, Fig. 8(c) に示寸実際の施工現場で確 認されているものと同様のものであり, 本実験で用いた単純模型試 験体が実際の梁端ウェブ接合部に近い応力状態を再現できたものと 考えられる。ただし, 実際の柱梁接合部では, 単純模型試験体に比 べて, 複雑なディテールとなるため, 各所の正味の熱伝達率に差異 が大きくなり, 温度勾配に伴う熱応力状態は単純模型試験体よりも 複雑になると考えられる。この点を踏まえためっき割れの発生メカ ニズムは今後の課題としたい。

割れ先端の走查型電子顕微鏡 $(\mathrm{SEM})$ による観察結果および亜鉛 (Zinc) の元素マッピングを Fig. 9 に示す。観察結果から, 割れは鋼中 の結晶粒界を伝播し，割れ内部に亜鉛が侵入していることを確認し た。既往の研究で確認されている鋼の溶接熱影響部に発生するめつ き割れと同様に，本実験で発生しためっき割れも，めっき浸漬中に 発生する液体金属脆化割れの一種である溶融亜鉛脆化割れであると 推定できる。

\subsection{2 温度履歴および歪履歴}

溶融亜鉛めっき浸漬時の温度履歴を Fig. 10 に示す。図の横軸は試 


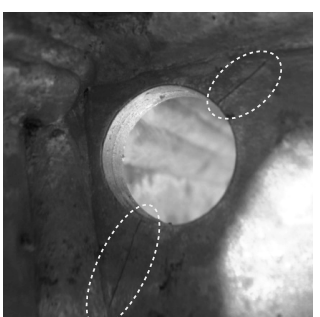

(i) Left side

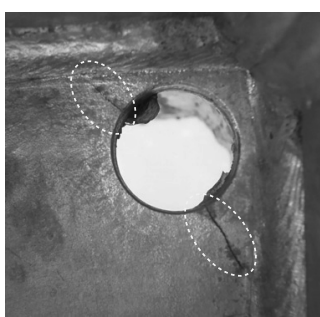

(ii) Right side

(a) Cracks observed in the test

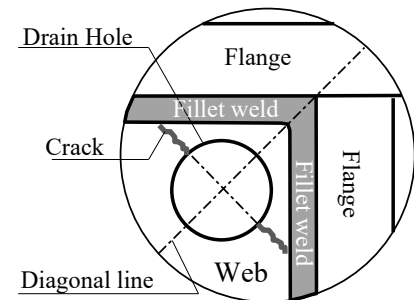

(b) Schematic diagram

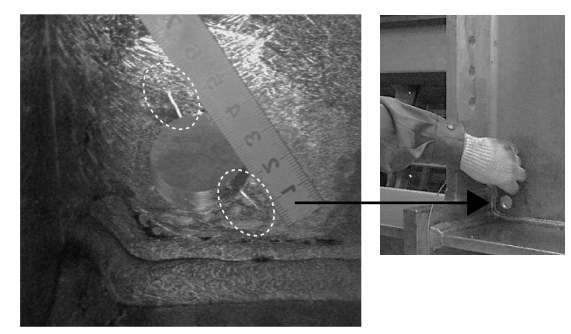

(c) Cracks observed in practice

Fig. 8 Diagonal cracks initiated from the edge of drain hole

験体が溶融亜鈶めっき内に浸漬を開始する時間を 0 とし，試験体の温 度が定常状態に至る $350 \mathrm{sec}$ までとしている。各図の上部には試験体 が全てめっき槽に浸漬するまでの状態を A, 試験体が全てめっき槽に 浸漬した後の状態を B として付記している。まず，ほぼ同一時点に 溶融亜鉛めっき内に浸漬されるフランジとウェブの温度履歴に着目寸 る。フランジ厚にかかわらず，ウェブ (t1 および $\mathrm{t} 2 ， ※ \mathrm{~T} 32$ の $\mathrm{t} 2$ は計 測不良)に比べて, フランジ (t4) の温度上昇が緩やかになっている。 次いで, ウェブ中央 $(\mathrm{t} 3)$ と円形孔周辺 (t1 と $\mathrm{t} 2)$ の温度履歴に着目寸る。 同じウェブであっても，ウェブ中央に比べて，円形孔周辺の方が温度 の上昇が緩やかになっている。これは隅角部周辺では，ウェブよりも 厚いフランジに囲まれるため, 溶融亜鉛めっき温度の低下を招き固体 亜鉛が付着する，また，亜鉛の再溶融に伴い熱量が奪われたため，正 味の亜鉛と鋼材間の熱伝達が低下したためと考えられる。温度履歴の 解析值と実験值を比較する。Fig. 10 に示すとおり，解析はフランジ 厚にかかわらず，実験の温度履歴をいずれの箇所でも良好に再現でき ていることが確認できる。

ウェブ中央と円形孔近傍における歪履歴を Fig. 11 に示す。歪の值 は引張を正とする。フランジ厚にかかわらず，円形孔近傍に生じる歪 はウェブ中央に比べて，はるかに大きくなっている。Fig. 10 に示し た温度履歴との対応をみると, 円形孔近傍では, 浸漬開始から 50 秒 程度でフランジとウェブの温度差が最大となっており，この時点で圧 縮歪も最大となる。その後, ウェブとフランジの温度差が小さくなる につれて，引張方向に歪が進展している。円形孔近傍の歪に着目して $\mathrm{T} 19$ と T32 を比較する。フランジ厚が厚い T32 の方が浸漬中に生じ る最大圧縮歪が大きくなっている。また，T32 では，鋼材内部の温度 差の減少に伴い, 引張方向に歪が進展寸る過程において, 歪が圧縮側 に急転する挙動がみられる。これは，この時点においてめっき割れが 生じことにより, 引張歪が解放されたためと考えられる。なお, 実験・ 解析ともに, 圧縮方向の塑性歪の進展に比べて, 引張側への塑性歪の 進展は小さく, 実験では小さな圧縮歪あるいは引張歪が残留した状態 で定常状態に至っている。すなわち，浸漬中に，大きな引張歪を経験 しなくとも，めっき割れを生じたことになる。これは，文献 16)で提 唱されている圧縮塑性歪を経験することで, 微小き裂が生成され，そ の後の温度差の減少による引張応力下で亜鉛の結晶粒界への侵入が促 されることでめっき割れが生じるとされるメカニズムに一致する結果 と考えられる。

歪履歴の実験值と解析值を比較する。解析はウェブ中央および円形 孔近傍のいずれの歪の進展挙動の傾向を概数捉えられている。ただし， 最大圧縮歪経験後の温度差の減少に伴う引張方向への進展挙動は, 実 験に比べて解析が明らかに緩やかとなっている。これは線形移動硬化
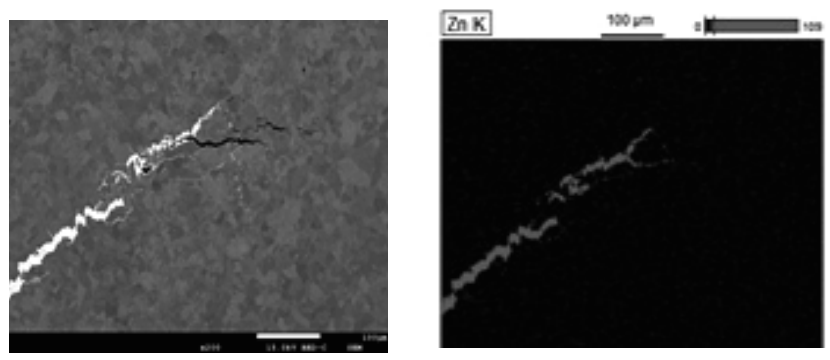

Fig. 9 Zinc diffused into cracking ( Microphotograph and Zinc mapping)

則を適用した本解析では，圧縮降伏を経験した後の引張方向への歪の 進展，すなわち，バウシンガー部の挙動を精度良く再現できないため と考えられる。一方で, 円形孔近傍の歪 (s1) について, 最大圧縮歪と 温度定常状態における歪の差分 (T32 は定常状態に至る前に割れが生 じたため, 最大圧縮歪と歪が圧縮側に急転する直前の時点の歪の差分） として定義される浸漬中の引張歪 $\Delta \varepsilon_{t}$ に着目する。 $\Delta \varepsilon_{t}$ を用いた理由は, $\Delta \varepsilon_{t}$ が先に述べためっき割れのメカニズムにおける微小き裂の生成要 因となりうる圧縮塑性歪と，結晶粒界一の亜鉛侵入を促寸引張応力の 影響の両方を考慮できる指標であるためである。 $\Delta \varepsilon_{t}$ の解析值と実験 值を比較する。 $\Delta \varepsilon_{t}$ についても解析が実験を過小評価する傾向にある。 一方で，フランジの板厚を 19 から $32 \mathrm{~mm}$ に厚くすることによる歪の 増加率は, 解析值が $50 \%$, 実験值が $46 \%$ であり, フランジ厚に増大 に伴う歪の増加傾向を定性的に捉えられているものと言える。

\subsection{3 めっき割れ発生位置の歪性状}

解析より得られた割れ発生位置の相当塑性歪分布を Fig. 12 に示寸。 Fig. 8 に示した割れ発生状況と対応寸るように，歪集中が円形孔周辺 にみられる。孔縁の最も歪が大きくなる要素から抽出した 45 度方向 の応力 - 歪関係と当該位置の温度履歴を Fig. 13 に示す。図中には応 力ー歪関係と温度履歴の対応を把握できるように, 各時点に○および 口を記す。45 度方向の定義は，先の歪ゲージと同一である。T19 お よび $\mathrm{T} 32$ ともに, 温度履歴との対応から, 当該位置が常温の状態で 圧縮降伏していることが確認できる。すなわち，当該位置は試験体の 上下の温度差に伴う熱応力によって降伏したものと言える。その後, 当該位置と周辺との温度差が減少寸るにつれて, 引張方向に歪が進展 し, 当該位置が $400^{\circ} \mathrm{C}$ 程度に達した時点で引張降伏を生じている。最 終的には温度が定常状態に至るまで引張方向に歪は進展していく。こ の応力 - 歪関係より求めた引張歪 $\Delta \varepsilon_{t}$ を両試験体で比較する。歪ゲー ジ貼付位置と同様に，めっき割れの発生起点と対応する位置において も $\Delta \varepsilon_{t}$ は T19 に比べて，T32 の方が $50 \%$ 程度大きくなっていることが 確認できる。 

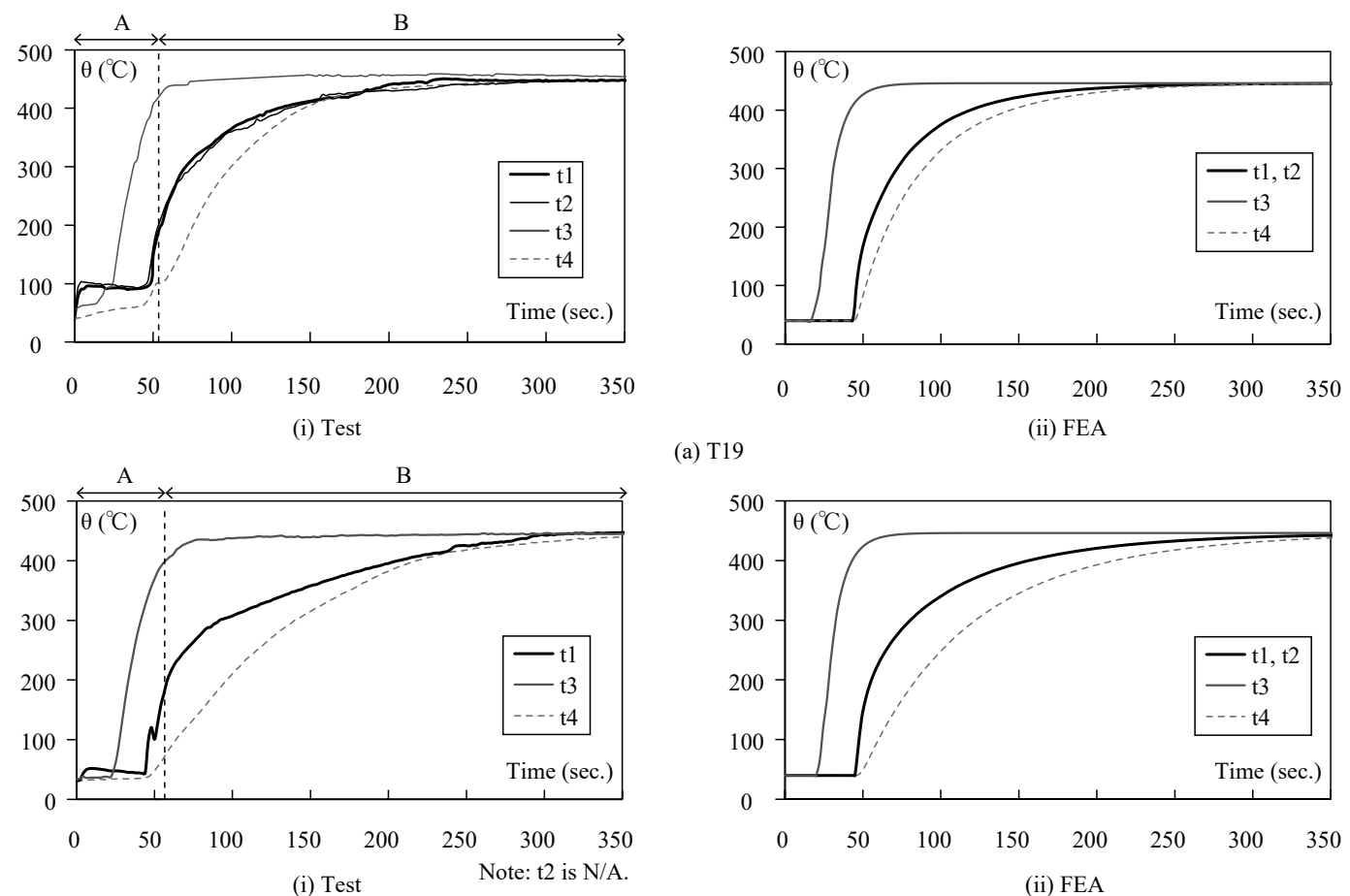

(a) T19

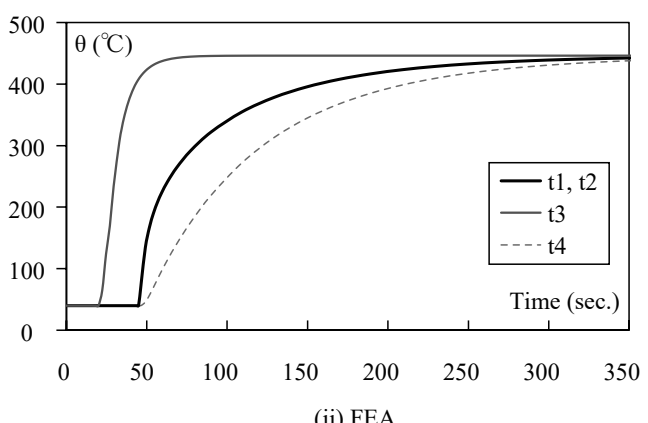

(b) $\mathrm{T} 32$

Fig. 10 Experimental and numerical temperature histories

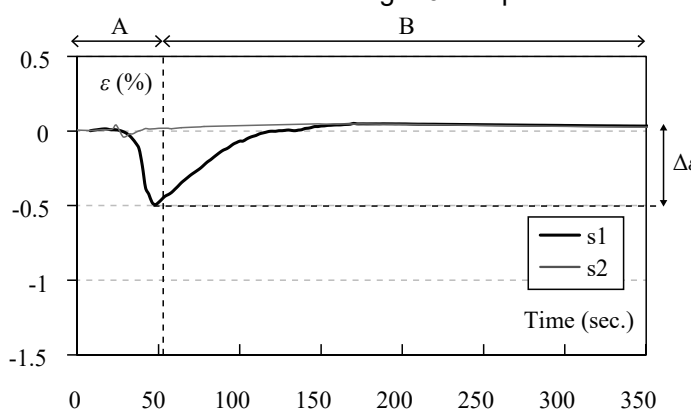

(i) Test

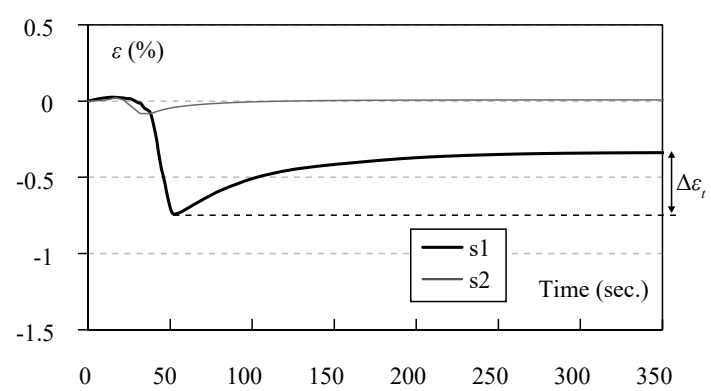

(a) T19

(ii) FEA

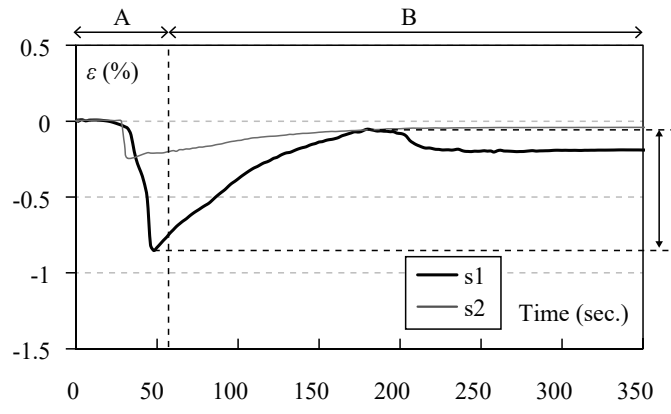

(i) Test

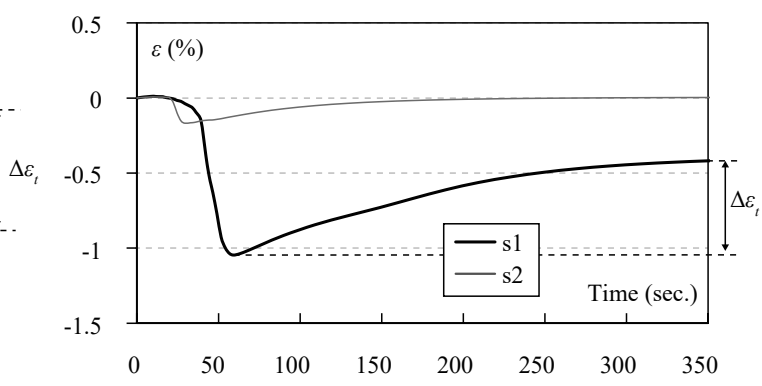

(ii) FEA

(b) $\mathrm{T} 32$

Fig. 11 Experimental and numerical strain histories

\section{3. パラメトリックスタディ}

\section{1 パラメータ}

各種幾何学的パラメータが円形縁の歪性状に与える影響および割 れ発生状況との対応を検討するため, 数值解析および浸漬実験による パラメトリックスタディを行った。試験体および解析ケースの一覧を Table 2 に示す。表中には実駼結果としてめっき割れ発生箇所数を併 記している。めっき割れの発生箇所数は円形孔の数としてカウントし た。本研究で考慮したパラメータをFig. 14 に図示する。パラメータは,
フランジ厚 $t_{f}$, ウェブ厚 $t_{w}$, 円形孔径および円形孔と溶接止端の最短 距離 $L$ である。フランジ厚 $t_{f}$ は $12 \sim 56 \mathrm{~mm}$ の 12 種類, ウェブ厚 $t_{w}$ は, 9,12 および $14 \mathrm{~mm} の 3$ 種類, 円形孔と溶接止端までの最短距離 $L$ は, 4， 9，14，24 および $40 \mathrm{~mm}$ の 5 種類 ( $L=24$ および $40 \mathrm{~mm}$ は解析のみ ), 円形孔径 $D$ は， 24 と $40 \mathrm{~mm}$ の 2 種類とした。また，実験ではウェブ 厚を $9 \mathrm{~mm}$ として, フランジ厚の影響を検討した実験を先行して行っ た結果, フランジ厚が $20 \mathrm{~mm}$ 前後で割れが顕著に増加したことから, その後に行った実験では，それほど大きなフランジ厚を考慮しなかっ 


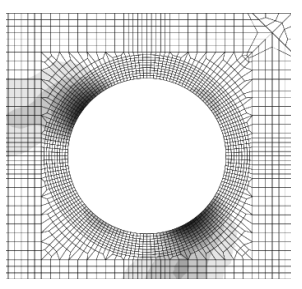

(a) $\mathrm{T} 19$

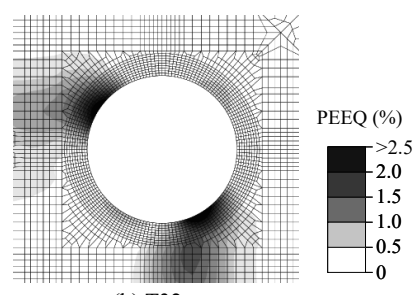

(b) T32

Fig. 12 Plastic strain distributions around drain hole on upper side

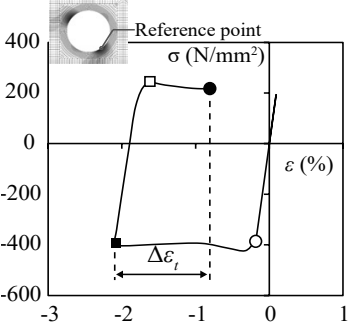

(i) Stress-strain relationships

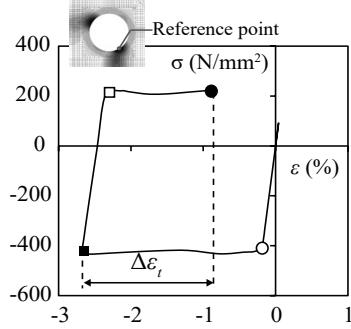

(i) Stress-strain relationships

(b) T32

Fig. 13 Stress-strain relationships and temperature histories

た。ただし, 解析はフランジとウェブの板厚比 $t_{f} / t_{w}$ が主要なパラメー タであることを考慮し, その他のパラメータの影響を, いずれも $t_{f} /$ $t_{w}$ を $1.33 \sim 4.00$ 程度まで変動させた上で検討できるように，試験体以 外の解析モデルを追加した。解析条件は, 先に示した解析と同一であ る。ただし，熱伝達率については，モデル全体を一律 $2500 \mathrm{~W} /\left(\mathrm{m}^{2} \cdot{ }^{\circ} \mathrm{C}\right)$ と設定した。これは. 2 章の解析では熱履歴も精度良く再現すること を試みて，フランジおよびフランジ近傍のウェブの熱伝達率を低減さ せたが，付録に示すとおり，めっき割れの発生位置である円形孔縁の $\Delta \varepsilon_{t}$ は，熱伝達率の差異によって $2 \%$ 程度と僅かな差であることが確 認できたためである。

\section{2 各パラメータの影響}

めっき割れ発生の起点となった円形孔縁の引張歪 $\Delta \varepsilon_{t}$ に基づき，各 パラメータの影響を検討する。各因子と $\Delta \varepsilon_{t}$ の関係を Fig. 15 に示す。

\section{【板厚比の影響】}

Fig. 15(a) より， $t_{f} / t_{w}$ が大きくなるにつれて顕著に $\Delta \varepsilon_{t}$ が大きくなつ ており, $t_{f} / t_{w}$ が大きくなるとやや $\Delta \varepsilon_{t}$ の值の上昇が緩やかになる傾向 にある。割れの発生状況との対応をみると, ウェブ厚を $9 \mathrm{~mm}$ とした 場合では, $t_{f} / t_{w}$ が 2.78 以上のときに，いずれも円形孔 4 箇所でめっ き割れを生じている (ID: 1-6 1-10)。

\section{【ウェブ厚の影響】}

Fig. 15(b) より, 同一の $t_{f} / t_{w}$ で比較すると, ウェブ厚 $t_{w}$ が厚いほど, $\Delta \varepsilon_{t}$ は小さく, いずれの $t_{f} / t_{w}$ でも, ウェブの板厚に概ね比例するよう に $\Delta \varepsilon_{t}$ は小さくなる傾向にある。 $t_{w}$ を $9 \mathrm{~mm}$ とした場合では, $t_{f} / t_{w}$ が 2.78 以上のとき (ID: 1-6 1-10) で，いずれもめっき割れを生じたが， $t_{w}$ を

Table 2 Parameter matrix and summary of test results

\begin{tabular}{|c|c|c|c|c|c|c|c|}
\hline \multirow[b]{2}{*}{ Paramter } & \multirow[b]{2}{*}{ ID } & \multirow{2}{*}{$\begin{array}{c}\mathrm{t}_{\mathrm{w}} \\
{[\mathrm{mm}]}\end{array}$} & \multirow[b]{2}{*}{$\begin{array}{c}\mathrm{t}_{\mathrm{f}} \\
{[\mathrm{mm}]}\end{array}$} & \multirow[b]{2}{*}{$\mathrm{t}_{\mathrm{f}} / \mathrm{t}_{\mathrm{w}}$} & \multicolumn{2}{|c|}{ Drain hole } & \multirow{2}{*}{$\begin{array}{c}\text { Num. of } \\
\text { D H Cracked }\end{array}$} \\
\hline & & & & & $\begin{array}{c}\mathrm{L}^{*} \\
{[\mathrm{~mm}]}\end{array}$ & $\begin{array}{c}\mathrm{D} \\
{[\mathrm{mm}]} \\
\end{array}$ & \\
\hline \multirow{10}{*}{$\begin{array}{c}\text { Thickness of } \\
\text { Flange }\end{array}$} & $1-1$ & \multirow{10}{*}{9} & 12 & 1.33 & \multirow{10}{*}{4} & \multirow{10}{*}{24} & 0 \\
\hline & $1-2$ & & 14 & 1.56 & & & 0 \\
\hline & $1-3$ & & 16 & 1.78 & & & 1 \\
\hline & $1-4$ & & 19 & 2.11 & & & 1 \\
\hline & $1-5$ & & 22 & 2.44 & & & 0 \\
\hline & $1-6$ & & 25 & 2.78 & & & 4 \\
\hline & $1-7$ & & 28 & 3.11 & & & 4 \\
\hline & $1-8$ & & 32 & 3.56 & & & 4 \\
\hline & $1-9$ & & 36 & 4.00 & & & 4 \\
\hline & $1-10$ & & 40 & 4.44 & & & 4 \\
\hline \multirow{12}{*}{$\begin{array}{c}\text { Thickness of } \\
\text { Web }\end{array}$} & $2-1$ & \multirow{6}{*}{12} & 16 & 1.33 & \multirow{12}{*}{4} & \multirow{12}{*}{24} & 0 \\
\hline & $2-2$ & & 19 & 1.58 & & & 0 \\
\hline & $2-3$ & & 22 & 1.83 & & & 0 \\
\hline & $2-4$ & & 25 & 2.08 & & & 0 \\
\hline & $2-5$ & & 32 & 2.67 & & & 0 \\
\hline & $2-6$ & & 48 & 4.00 & & & - \\
\hline & $3-1$ & \multirow{6}{*}{14} & 19 & 1.36 & & & 0 \\
\hline & $3-2$ & & 22 & 1.57 & & & 0 \\
\hline & $3-3$ & & 25 & 1.79 & & & 0 \\
\hline & $3-4$ & & 28 & 2.00 & & & 0 \\
\hline & $3-5$ & & 36 & 2.57 & & & 0 \\
\hline & $3-6$ & & 56 & 4.00 & & & - \\
\hline \multirow{16}{*}{$\begin{array}{c}\text { Position } \\
\text { of } \\
\text { Drain Hole }\end{array}$} & 4-1 & \multirow{16}{*}{9} & 16 & 1.78 & \multirow{5}{*}{9} & \multirow{16}{*}{24} & 0 \\
\hline & $4-2$ & & 19 & 2.11 & & & 0 \\
\hline & $4-3$ & & 22 & 2.44 & & & 1 \\
\hline & $4-4$ & & 25 & 2.78 & & & 2 \\
\hline & $4-5$ & & 32 & 3.56 & & & - \\
\hline & $5-1$ & & 19 & 2.11 & \multirow{8}{*}{24} & & 1 \\
\hline & $5-2$ & & 22 & 2.44 & & & 0 \\
\hline & $5-3$ & & 25 & 2.78 & & & 0 \\
\hline & $5-4$ & & 28 & 3.11 & & & 0 \\
\hline & $5-5$ & & 32 & 3.56 & & & 0 \\
\hline & 24-1 & & 16 & 1.78 & & & - \\
\hline & $24-2$ & & 22 & 2.44 & & & - \\
\hline & 24-3 & & 32 & 3.56 & & & - \\
\hline & $40-1$ & & 16 & 1.78 & \multirow{3}{*}{40} & & - \\
\hline & $40-2$ & & 22 & 2.44 & & & - \\
\hline & $40-3$ & & 32 & 3.56 & & & - \\
\hline & $10-1$ & & 14 & 1.56 & & & 0 \\
\hline & $10-2$ & & 16 & 1.78 & & & 0 \\
\hline Diameter of & $10-3$ & 9 & 19 & 2.11 & 4 & 40 & 0 \\
\hline Drain Hole & $10-4$ & 9 & 22 & 2.44 & 4 & 40 & 0 \\
\hline & $10-5$ & & 32 & 3.56 & & & - \\
\hline & $10-6$ & & 40 & 4.00 & & & - \\
\hline
\end{tabular}

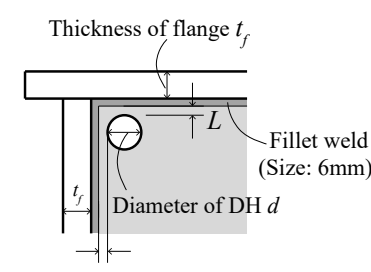

Shortest distance between DH and weld toe $L$

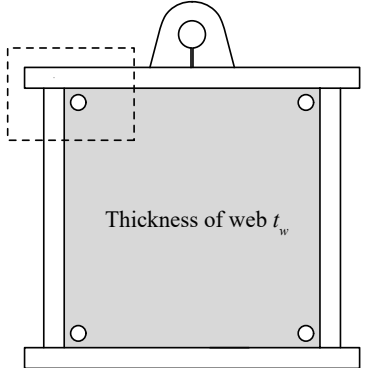

Fig. 14 Geometric parameters considered in this study

12 mm(ID: 2-1 2-6) および 14 mm(3-1 3-6) の場合では, 板厚比を 2.78 以上としたときでも，めっき割れを生じていない。以上より，ウェブ 厚を厚くすることによる歪低減がめっき割れを防止できた主因と考え られる。一方で, 本実験で使用した鋼材の CEZ は， $t_{w}$ が $9 \mathrm{~mm}$ の場合 に比べて，12 および $14 \mathrm{~mm} の$ 方が小さくなっている。従って，文献 17）で報告したように，母材原質部に生じるめっき割れであっても, 


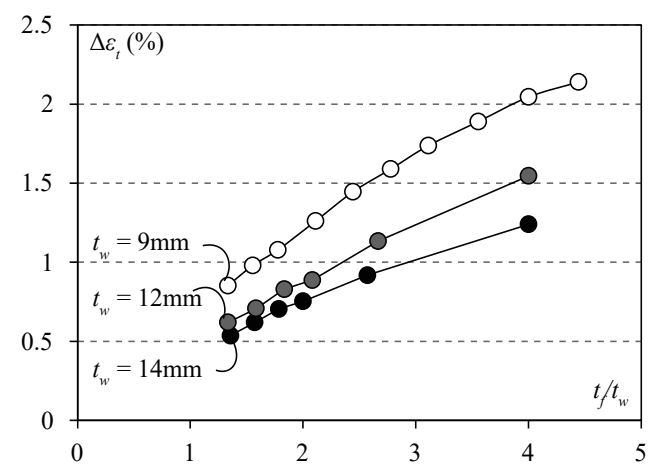

(a) Effect of flange-to-web thickness ratio

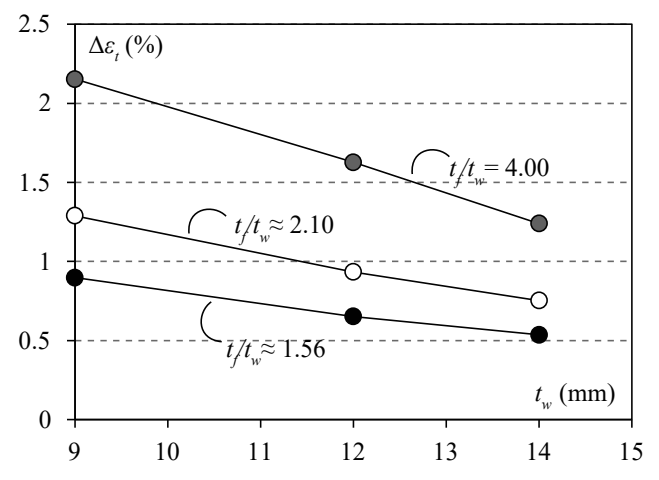

(b) Effect of thickness of web

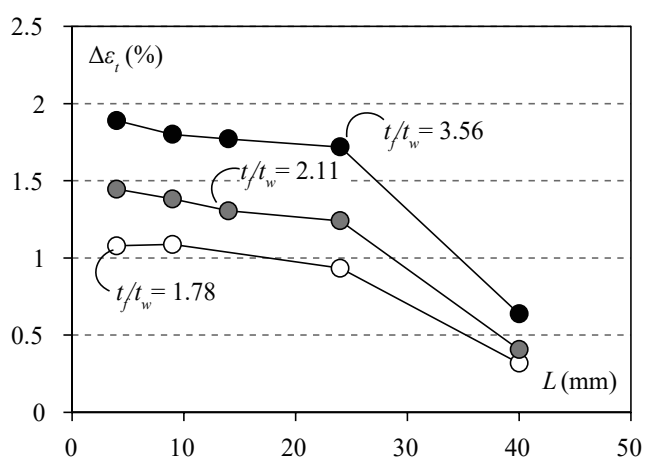

(c) Effect of distance between DH and weld toe

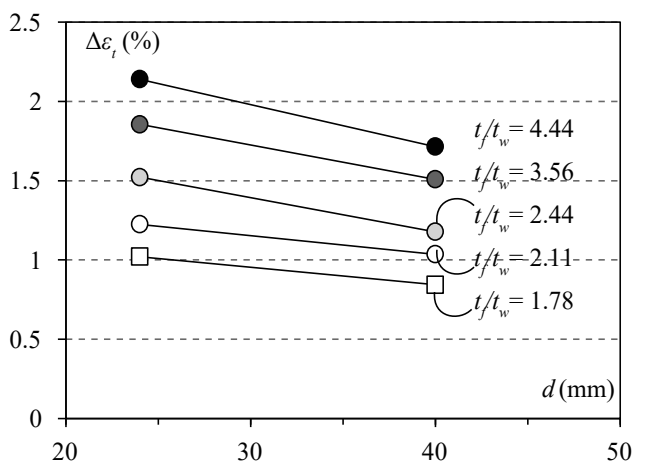

(b) Effect of diameter of drain hole

Fig. 15 Effect of geometric parameters on tensile strain

CEZ の影響もあったものと考えられる。

\section{【円形孔と溶接止端の距離の影響】}

Fig. 15(c)より， $t_{f} / t_{w}$ によって，めっき抜き孔位置 $L$ が $\Delta \varepsilon_{t}$ へ及ぼす 影響に，若干異なる傾向がみられる。ただし，全体として $L$ をか

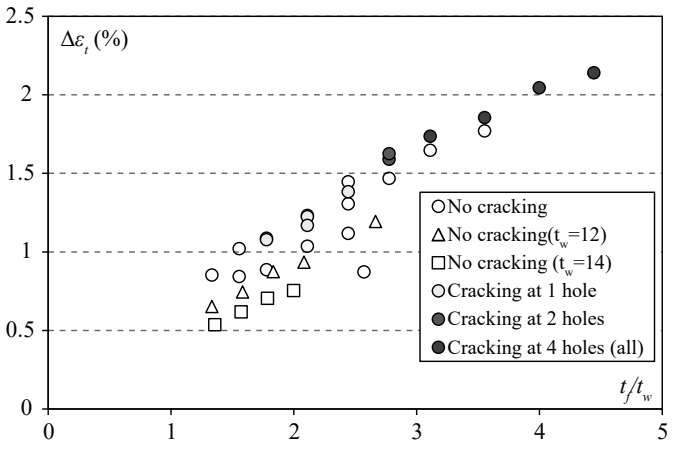

Fig. 16 Correlation between tensile strain and crack occurrences

ら $24 \mathrm{~mm}$ に大きくした場合の, $\Delta \varepsilon_{t}$ の低減は最大で $12 \%$ 程度と小さい。 実験でも $L=9 \mathrm{~mm}$ の場合， $t_{f} / t_{w}$ が 2.44 および 2.78 のときに，それぞ れめっき割れが 1 箇所 (ID: 4-3) および 2 箇所 (ID: 4-4) 発生し, $L=14$ $\mathrm{mm}$ とした場合では, $t_{f} / t_{w}$ が 2.11 のときに 1 箇所 (ID: 5-1) 発生してい る。一方で， $L$ を円形孔の 1.7 倍程度の $40 \mathrm{~mm}$ とした場合では，いず れの $t_{f} / t_{w}$ でも $\Delta \varepsilon_{t}$ は大きく低減されている。しかしながら，Lを円形 孔径の 2 倍近くに大きくすれば，隅角部の空気およびめっき抜きとし ての機能に支障をきたすものと予想される。以上より，めっき抜き孔 としての機能を担保できる範囲で $L$ を大きくすることは，それほど 大きな歪低減効果を見込めないものと考えられる。ただし，溶接止端 に近づけば, その分だけ溶接残留応力も大きくなるため, 溶接残留応 力を低減するという観点では， $L$ を確保することの効果はあるものと 考えられる ${ }^{2)}$

\section{【孔径の影響】}

Fig. 15(d) より，いずれの $t_{f} / t_{w}$ においても，孔径 $D$ を大きくするこ とで， $\Delta \varepsilon_{t}$ は低減されている。また， $t_{f} / t_{w}$ にかかわらず， $D$ を 24 から $40 \mathrm{~mm}$ と 1.7 倍程度に大きくすることで, $20 \%$ 程度の歪低減が得られ ている。また， $D$ を $40 \mathrm{~mm}$ とした場合は， $t_{f} / t_{w}$ が 2.44 以下の実験結 果 (ID:10-1 10-4) のみになるが，いずれもめつき割れを生じていない。

\section{3 めっき割れ発生状況と引張歪の相関}

全試験体を対象として, めっき割れ発生状況と引張歪 $\Delta \varepsilon_{t}$ の相関を みるため, $\Delta \varepsilon_{t}$ と $t_{f} / t_{w}$ の関係を Fig. 16 に示す。各種パラメータにかか わらず, $\Delta \varepsilon_{t}$ が増加することで割れ発生数が顕著に増大する傾向が見 て取れる。すなわち, 割れの起点となる孔縁に生じる $\Delta \varepsilon_{t}$ は, 各種幾 何学的パラメータが割れ発生に与える影響を評価する有効な指標と言 える。なお, $\Delta \varepsilon_{t}$ が $1.5 \%$ 以上と大きい場合でも 2 体の試験体ではめつ き割れを生じていない。これは使用鋼材のめっき割れの感受性に大き な影響を及ぼす元素であるボロンなどの偏析によって生じたばらつき であると考えられる。一方で，そのようなばらつきは認められるもの の，本実験で使用した鋼材 SN490B の場合では， $\Delta \varepsilon_{t}$ を $1.0 \%$ 以下に留 められたときにいずれもめっき割れを生じていない。従って，工作物 の形状を適正化し，めつき割れを防止を図ることは有効な手段である ことが改めて確認されたものと言える。ただし， $\Delta \varepsilon_{t}$ は，鋼材の強度 によっても大きく変化する指標である ${ }^{17)}$ 。今後材料強度 $($ 鋼種 $)$ にか かわらず，使用可能な指標を提示するためには，材料強度および化学 組成 (CEZ) を含めて, 総合的に分析していく必要があり, この点に ついては稿を改めて報告したい。 


\section{4. おわりに}

本論では，めっきおよび空気抜き孔として設けられた円形孔を起 点に発生するめっき割れを対象とし，めっき割れに及ぼす幾何学的パ ラメータの影響を単純模型試験体を用いた浸漬実験および熱伝導一熱 応力解析によって検討した。以下に得られた知見を示す。

1) フランジ厚をパラメータとした浸漬測定実験より，フランジ厚を 厚くすることで, 円形孔縁の歪が増大し, $9 \mathrm{~mm}$ のウェブに対して, $32 \mathrm{~mm}$ のフランジとした試験体では, 試験体上部の 2 箇所にてめっ き割れが生じた。また，割れの顕微鏡 (SEM)による観察結果およ び円形孔近傍の歪挙動から，めっき割れが溶融亜鉛めっき浸漬中 に生じたことを確認した。

2) 溶融亜鉛浸漬中の円形孔縁の歪集中点で生じる最大圧縮歪と定常 状態における歪の差分として定義される引張歪とめっき割れの発 生状況には明確な相関がみられ, 引張歪が大きくなることで, めっ き割れが顕著に増大した。

3) 同一の板厚比であっても, ウェブ厚を厚くすることで, 引張歪を 低減することができ，板厚比だけでなく，ウェブの板厚を厚くす ることもめっき割れ防止において有効な方策と言える。

4) 円形孔の径を $24 \mathrm{~mm}$ から $40 \mathrm{~mm}$ と 1.7 倍程度大きくすることで。 めっき割れ発生の起点となる位置の引張歪を約 $20 \%$ 程度低減する ことが期待できる。

5) めつき抜き孔としての機能を損なわない程度の範囲 (L=4 24 mm) において，円形孔縁と溶接止端の距離を大きくすることによる引 張歪の低減は小さい。

本研究は SN490B 材を対象として検討を行ったが，めっき割れは， 鋼種が異なることによって変化する材料強度および化学組成の影響も 受けるものと考えられる。また, 本研究の単純模型試験体と実大構造 物における浸漬中の応力状態の差異も明確にしておく必要があるもの と考えられる。これら点について今後の課題である。

\section{謝辞}

本研究で行った磁粉探傷試験はジャスト株式会社・古舘岳実氏の 協力を得て実施した。また, 本研究は, 元神戸大学院生（現清水建設）・ 高倉正幸氏が修士論文で取り組んだ研究を継続・発展させたものであ る。ここに記して深甚なる謝意を表す。

\section{付録 熱伝達率が円形孔縁の引張歪に与える影響}

板厚が厚いフランジや， 円形孔が存在する隅角部周辺では，溶融亜鉛めっき 温度の低下による固体亜鉛の付着などによって正味の亜鉛と鋼材間の熱伝達が は低下するものと考えられる。ただし，この熱伝達の低下は板厚，フランジと ウェブの板厚の組み合わせ，浸漬条件などによっても変化するものと考えら れ，その影響を定量的に評価することは現状ではできない。そこで，T19およ びT32を対象として，フランジとフランジ近傍のウェブの熱伝達率の低下が円 形孔縁の $\Delta \varepsilon_{t}$ に与える影響を数值解析によって検討する。フランジとフランジ 近傍のウェブの熱伝達率のみを変化させた場合の引張歪を Fig. A1 に示す。ウェ ブ中央の熱伝達率は 2 章の解析と同一の $2500 \mathrm{~W} /\left(\mathrm{m}^{2} \cdot{ }^{\circ} \mathrm{C}\right)$ とし, フランジとフ ランジ近傍のウェブの熱伝達率は，2500（ウェブ中央と同一)，1200（2 章の解 析と同一の設定), $600 \mathrm{~W} /\left(\mathrm{m}^{2} \cdot{ }^{\circ} \mathrm{C}\right)$ の 3 種類とした。フランジおよびウェブ近 傍の熱伝達率の低下に伴い， $\Delta \varepsilon_{t}$ は若干増加する傾向がみられる。ただし，ウェ ブ中央に対して, 熱伝達率を $1 / 2$ 程度 $\left(=1200 \mathrm{~W} /\left(\mathrm{m}^{2} \cdot{ }^{\circ} \mathrm{C}\right)\right.$ に低下させた場合, $\Delta \varepsilon_{t}$ の増加は最大 $2 \%$ 程度, $1 / 4$ 程度 $\left(=600 \mathrm{~W} /\left(\mathrm{m}^{2} \cdot{ }^{\circ} \mathrm{C}\right)\right.$ に低下させた場合でも, $\Delta \varepsilon_{t}$ の増加は最大で $4 \%$ 程度である。熱伝達率の低下が $\Delta \varepsilon_{t}$ に与える影響は非常 に小さいことが確認できる。

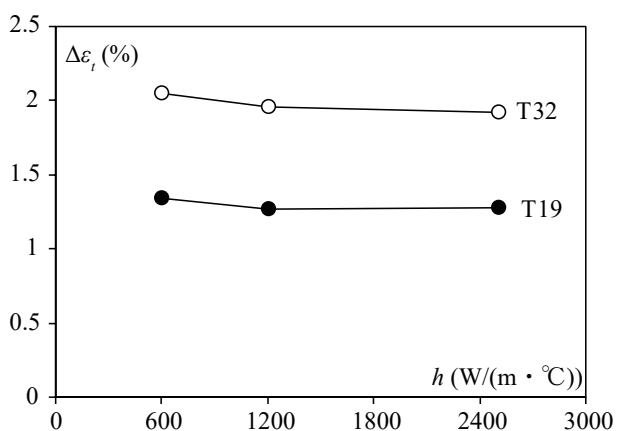

Fig. A1 Impact of heat conductivity at flanges and web near the flange on tensile strain

\section{参考文献}

1) Koyama, A., Iwasaki, M., Nagata, S., Jikihara, A.: Study on Galvanizing Cracks on Scallap of Steel Column Connection Joints, QUARTERLY JOURNAL OF THE JAPAN WELDING SOCIETY, Vol. 22, Issue 3, Pages 435-442, 2004. (in Japanese)

小山 明久, 岩崎 雅紀, 永田 晋, 直原 明 : 鉄骨柱仕ロスカラップの溶融亜鉛 めっき割れに関する検討, 溶接学会論文集, 第 22 巻, 第 3 号, pp. 435-442, 2004

2) Mori, M., Nakagomi, T., Suzuki, I., Kim, C.: Source and Prevention of Cracking of Hot-Dip Galvanization Coating for Steel Beam-Column Joints, QUARTERLY JOURNAL OF THE JAPAN WELDING SOCIETY, Vol. 27, Issue 1, pp.41-47, 2009. (in Japanese)

護 雅典, 中込忠男, 鈴木 至, 金昌秀: 柱梁接合部における溶融亜鉛めっき 割れ発生原因とその防止法, 溶接学会論文集, 第 27 巻, 第 1 号, pp. 41-47, 2009.

3) Nishio, Y., Iwasaki, S., Deto, H., Onishi, H.: Examination using ThreeDimensional Thermal Conductivity - Thermal Stress Analysis for Prevention of Galvanizing Cracks during Hot Dip Galvanizing of Steel Structures, Journal of Japan Society of Civil Engineers, Ser. A2 (Applied Mechanics (AM)), Vol. 69, Issue 2, pp.I_615-I_624, 2013. (in Japanese)

西尾吉史, 岩崎正二, 出戸秀明, 大西弘志 : 3 次元熱伝導 - 熱応力解析に よる鋼構造物の溶融亜鈆めっき割れ対策に関する検討, 土木学会論文 集 A2 (応用力学), Vol. 69, No. 2 (応用力学論文集 Vol. 16), pp.I_615-I_624, 2013.

4) Yamashita, T., Nishizawa, J., Tanaka, T., Asada, H., Takakura, M., Furudate, T. Study on Liquid Metal Assisted Cracking at Welded Web Connection Caused by Hot-dip Galvanizing, Summaries of Technical Papers of Annual Meeting, Architectural Institute of Japan, Materials and Construction, pp.1147-1154, 2016. 8 (in Japanese)

山下達雄, 西澤淳, 田中剛, 浅田勇人, 高倉正幸, 古館岳実：梁 端 ウェブ接合部に発生する溶融亜鉛脆化割れに関する研究 その 1 その 4 , 日本建築学会大会学術講演梗概集, 材料施工, pp.1147-1154, 2016.8

5) Architectural Institute of Japan: Japanese Architectural Standard Specification, (JASS 6), 2018

日本建築学会 : 鉄骨工事標準仕様書 (JASS6), 2018.

6) Architectural Institute of Japan: Techinical Recommendation for Steel Construction for Buildings (Part 1 Guide to Steel-rib Fabrications), 2018. 4. (in Japanese)

日本建築学会 : 鉄骨工事技術指針・工場製作編, 2018.4

7) Takeda, T., Kanaya, K., Yamato, K., Eiro, K., Chano Z., Kanazawa, S., Hiroki, T., Iezawa, T.: Development of $60 \mathrm{kgf} / \mathrm{mm} 2$ Steel for Power-transmission Pipe Tower and Its Resistance to Liquid Zinc Embrittlement, Tetsu-to-Hagane, Vol. 70, Issue 6, pp. 596-602, 1984. (in Japanese)

武田 鐵治郎, 金谷 研, 山戸一成, 永露 清次 , 茶野 善作, 金沢 正午, 広木 光雄, 家沢 徹: 鋼管鉄塔用 $60 \mathrm{kgf} / \mathrm{mm} 2$ 鋼の開発と而溶融亜鉛ぜい化の検討, 鉄と鋼, 第 70 巻, 第 6 号, pp. 596-602, 1984.

8) Fujimoto, M., Kanazawa, S.: Development of new $60 \mathrm{kgf} / \mathrm{mm} 2$ high tensile strength steel (new HT60) for power transmission tower and its specification (temporary) - Pipe, plate, angle, flange and welding material-, JSSC, Vol. 21, No. 221, pp.11-45, 1985. 2. (in Japanese) 藤本 盛久, 金沢 正午: 送電鉄塔用 $60 \mathrm{kgf} / \mathrm{mm}^{2}$ 高張力鋼 (新 HT60) の開発と, 
その鋼材規格 (案), JSSC, VOL.21, No.221, pp.11-45, 1985. 2

9) Iezawa, T., Inoue, N., Hirano, K., Okazawa T., Ozeki, T.: Effect of Boron on Liquid Zinc Induced Embrittlement in Heat Affected Zone of STK590 Steel Tube for Power Transmission Tower, Transactions of the Iron and Steel Institute of Japan, Vol. 79, No. 9, pp.1108-1114, 1993. (in Japanese)

家澤徹, 井上尚志, 平野攻, 岡沢亨, 小関智也: 送電鉄塔用鋼管 STKT590 溶接熱影響部の溶融亜鈶めつきぜい化に及ぼす微量ボロンの影 響, 鉄と鋼, 第 79 巻,第 9 号, pp. 1108-1114, 1993.

10) Takeda T.: Evaluation Method of Zinc Induced Cracking, Quarterly Journal of The Japan Welding Society, Vol.71, Issue 4, pp.32-38, 2002. (in Japanese) 武田 鐵治郎 : 亜鉛めつき割れ評価法, 溶接学会誌, 第 71 巻, 第 4 号, pp. 234-240, 2002.

11) Mori, M., Nakagomi, T., Suzuki, I., Kim, C.: Proposal of Prevention Method on Cracks at Hot-Dipped Galvanization of Rectangular Hollow Section Steel Pipes by Cold Forming, Journal of Structural and Construction Engineering (Transactions of AIJ), Volume 74, No. 638, pp.739-746, 2009. 4 (in Japanese)

護 雅典, 中込忠男, 鈴木 至, 金昌秀: 冷間成形角形鋼管におけるめっき割 れ防止方法, 日本建築学会構造系論文集, 第 74 巻, 第 638 号, pp.739-746, 2009. 4

12) ABAQUS: ABAQUS/ Standard user's manual. version 6.11-2, 2011

13) Nagano, M., Mikami, Y., Miyazawa T., Kanaya K., Yoshida K., Shinniwa, Y.: Prediction and Prevention of Liquid Zinc Induced Cracking in Tubular Structures of 590MPa Steel Based on Elastic-Plastic-Thermal Stress Analysis, Journal of High Pressure Institute of Japan, Vol. 41, Issue 1 pp.17-27, 2003. (in Japanese)
長野眞康, 三上 康朗, 宮澤 健博, 金谷 研, 吉田一弘, 新岩 吉昭 : $590 \mathrm{MPa}$ 級鋼管構造物の溶融亚鉛めっきぜい化割れに対する弾塑性熱応力解析に基 づく予測と防止対策, 圧力技術, Vol.41, No.1, pp.17-27, 2003.

14) Architectural Institute of Japan: Recommendations for Fire Resistant Design of Steel Structures, The Second Edition, 2017. 6 (in Japanese) 日本建築学会 : 鋼構造而火設計指針, 第 2 版, 2017.6

15) Lie T.T.: Structural Fire Protection, ASCE, 1992.

16) Takeda, T.: Effect of Compressive Platic Strain on the Occurrence of Zinc Induced Cracking, Journal of High Pressure Institute of Japan, Vol. 54, No. 5, pp. 237-243, 2016. (in Japanese)

武田 鐵治郎: Zn われ発生に及ぼす圧縮塑性ひずみの影響についての一考 察, 圧力技術, Vol. 54, No. 5, pp. 237-243, 2016.

17) Fujiwara, Y., Asada, H., Tanaka, T., Yamashita., T., Miyasaka, J.: An Investigation on Effect of Material Properties on Liquid Metal Assisted Cracking at Welded Web Connection Caused by Hot-dip Galvanizing, Proceeding of AIJ Kinki Branch, Vol. 58, pp.10-13, 2018. (in Japanese)

藤原 有希, 浅田勇人, 田中剛, 山下 達雄, 宮坂 淳一: 梁端ウェブ接合 部に設けられためっき抜き円形孔に発生する溶融亜鉛めっき割れに及ぼ す鋼材特性の影響, 日本建築学会近畿支部研究報告集, 第 58 号, pp.10-13, 2018. 


\title{
FUNDAMENTAL STUDY ON LIQUID METAL ASSISTED CRACKING OCCURRED AT VENT AND DRAIN HOLES DURING HOT-DIP GALVANIZING
}

\author{
Hayato ASADA*1, Tsuyoshi TANAKA*2, Tatsuo YAMASHITA*3 \\ and Yuki FUJIWARA*4 \\ ${ }^{* 1}$ Assist. Prof., Dept. of Architecture, Kobe University, Dr.Eng. \\ ${ }^{* 2}$ Prof., Dept. of Architecture, Kobe University, Dr.Eng. \\ ${ }^{* 3}$ Kakuto Corporation, Dr.Eng. \\ ${ }^{* 4}$ Shimizu Corporation, M.Eng. (Former Grad. Student, Kobe University)
}

Hot-dipped zinc coating is well recognized as a standard method of long-term protection from corrosion and is widely applied to heavy steel products such as building structures in Japan. In this process, liquid metal assisted cracking (LMAC) has sometimes occurred at vent and drain holes which were located at the corner of welded beam-to-column connection during hot-dip galvanizing. However, the mechanism of the phenomenon has not been well understood. To develop the understanding of the phenomenon, This study focuses on the effect of geometrical parameters such as the flange-to-web thickness ratio, the web thickness, the diameter of the holes, and their position on LMAC to develop the understanding of the mechanisms through which LMAC that initiated from the edge of holes and seek to identify an effective way for preventing them in practice. As the pilot study, Immersion tests were performed with scaled test specimens to investigate the thermal and strain histories due to the thermal expansion and contraction in hot-dip galvanizing process. A companion analytical model shown in Fig. 4, which is capable of simulating the test results was developed. The verified numerical model was used to develop the helpful index for evaluating the effect of geometric parameters on LMAC, in term of the tensile strain at the point corresponding to LMAC occurrence shown in Fig, 11. From the investigations, the following conclusions were drawn:

Immersion testing with the flange thickness as the test parameter showed that as the flange thickness increases, the strain at the circular hole edges also increases. For a web thickness of $9 \mathrm{~mm}$, LMAC occurred at two locations at the top of the test specimen when $32 \mathrm{~mm}$ flange was attached. Furthermore, microscope images (SEM) of the cracks and the behavior of the strain in the vicinity of the circular holes showed that the LMAC occurred while the test specimen was immersed in the molten zinc.

Increases in the tensile strain, which is defined as the difference between the maximum compressive strain at the strain concentration point at the edge of the circular holes during and the strain at steady state, cause significant increases in LMAC.

As the flange-to-web thickness ratio increases, the tensile stress that occurs at the hole edges increases as well, and the occurrence of cracking also increases significantly. However, even for cases in which the flange-to-web thickness ratio is the same, it is possible to reduce the tensile strain by increasing the web thickness. Therefore, increasing the web thickness, as well as reducing the flange-to-web thickness ratio, is effective in preventing cracking.

Increasing the diameter of the circular holes by a factor of 1.7 results in an approximately $20 \%$ reduction in the tensile strain. Increasing the distance between the circular hole edges and the weld toes within the range over which the holes still function as drain holes $(\mathrm{L}=4-24 \mathrm{~mm})$ has small effects on reducing the tensile strain. 